The historiography on Soviet experience in WWII has become expansive, yet women's roles and experiences under occupation require further study. Soviet women have either been written into history as victims of violence, rape, hunger and deportation on both sides of the frontline ${ }^{1}$ or as brave soldiers, pilots and snipers. ${ }^{2}$ Scholars continue to explore the gender relationships within the Red Army and address the adversities the female combatants faced during and after the war, including sexual harassment, discrimination and stigma attached to the returning front-women. ${ }^{3}$ The representation of women combatants in the official Soviet discourse and popular culture also continue to be explored. ${ }^{4}$ However, there appears to be a gap in the historiography concerning

\footnotetext{
${ }^{1}$ Women are mentioned briefly, and in the context of the breakdown of family in John Barber and Mark Harrison, The Soviet Home Front 1941-1945: A social and economic history of the USSR in World War II (London and New York: Longman, 1991), pp. 90-93.

On women as victims of sexual violence see Jeffrey Burds, "Sexual violence in Europe in World War II, 19391945," in Politics \& Society, 2009, vol. 37, (1).

On the topic of women in exile or forced migration in the Soviet Union during the war see Pavel Polian, Zhertvi tvukh diktatur: Sovetskie voennoplennie I ostarbaiteri v Tretiem reikhe I ikh repatriatsiya (Moscow: Vash Vibor Tsirz, 1996); Katherine R. Jolluck, Exile and Identity: Polish Women in the Soviet Union during World War II (Pittsburgh: University of Pittsburgh, 2002); Rebecca Manley, To the Tashkent Station: Evacuation and survival in the Soviet Union at War (New York: Cornell University Press, 2009).

${ }^{2}$ Russian language literature on Soviet women as soldiers began appearing as early as 1947, see Nina V. Popova, Zhenschiny strany sotsializma (Moscow: Profizdat, 1947), and continued into the 70s and 80s with Vera S. Murmantseva, Sovetskie zhenschiny v Veliko Otechestvennoi voine (Moscow: Mysl', 1974); Valentina I. Galgan, Ratnyi podvig zhenschin v gody Velikoi Otechestvennoi voiny (Kiev: Vyscha shkola, 1986); Svetlana Aleksievich, U voiny - ne zhenskoe litso. Poslednie svideteli (Moscow: Sovetskii pisatel', 1987). The subject of women soldiers has also acquired attention from Western scholars, see John Erikson, "Soviet women at war" in John Garrard and Carol Garrard (eds.), World War 2 and the Soviet people (New York: St. Martin's Press, 1993); Reina Pennington, “Offensive Women: Women in Combat in the Red Army," in Paul Addison and Angus Calder (eds.), Time to Kill. The Soldier's Experience of War in the West 1939-1945, (London: Random House, 1997), pp. 249-262; Barbara A. Engel, "The Womanly face of War. Soviet Women Remember World War II," in Nicole A. Dombrowski (ed.), Women and War in the Twentieth Century. Enlisted with or without Consent, (New York and London: Garland Publishing, 1999), pp. 138-159; Susanne Conze and Beate Fieseler, "Soviet Women as Comrades-in-Arms: A blind spot in the History of the War," in Robert W. Thurston and Bernd Bonwetsch (eds.), The People's War. Responses to World War II in the Soviet Union (Urbana and Chicago: University of Illinois Press, 2000), pp. 211-233.

In recent years scholars has focused on small groups of elite professional women combatants in the Red Army. See Reina Pennington, Wings, Women, and War: Soviet airwomen in World War Il combat (Lawrence: University Press of Kansas, 2001); Anna Krylova, Soviet women in combat: a history of violence on the Eastern Front (Cambridge: Cambridge University Press, 2010);Rodger D. Markwick and Euridice Charon Cardon, Soviet women on the frontline in the Second World War (New York: Palgrave Macmillan, 2012).

3 Juliane Furst, "Heroes, Lovers, Victims - Partisan Girls during the Great fatherland War: analysis of documents from the spetsotdel of the Komsomol Archive," Minerva; Quarterly report on women and the military, vol. 18, no. 3-4, 2000, pp. 38-75; Kirsten Bischl, "Telling Stories. Gender relationships and masculinity in the Red Army 1941-1945,"in M. Roger and R. Leiserowitz (eds.), Women and Men at War: A Gender Perspective on World War II and its Aftermath in Central and Eastern Europe (Osnabruck: Fibre, 2012), pp. 117-134;O.V. Budnitskii, "Muzhchiny I zhenshchiny v Krasnoi Armii (1941-1945)," Cahiers du monde russe, vol. 52, no. 2, 2009, pp. 240-262; Catherine Merridale, "Masculinity at war: Did gender matter in the Soviet army?," Journal of War and Cultural Studies, vol. 5, no. 3, 2012, pp. 307-320; Brandon M. Schechter, "'Girls' and 'Women'. Love, Sex, Duty and Sexual Harassment in the Ranks of the Red Army 1941-1945," The Journal of Power Institutions in Post-Soviet Societies, no. 17, 2016, pp.

${ }^{4}$ Adrienne M. Harris, The Myth of the Woman Warrior and World War II in Soviet Culture, Ph. D. Dissertation, University of Kansas, 2008; Karel Berkhoff, Motherland in danger: Soviet propaganda during World War II
} 
civilian Soviet women and their experiences under occupation. Historians studying civilian life under occupation often focus on the German occupation policies and economic and living conditions, yet despite women comprising more than fifty percent of the civilian population, their experiences in these discussions are seldom highlighted. ${ }^{5}$ Women have been discussed as having agency on the Soviet side of the battlefield, but those who remained under enemy occupation have been largely neglected.

Literature on Soviet civilian resistance or collaboration during World War II continues to grow, yet the narrative of a female resister or collaborator remains largely unexplored. ${ }^{6}$ Women continue to be trapped by the stereotype of sexual collaborator: an accommodating sexual partner or victim of sexual violence and exploitation. ${ }^{7}$ Recently Olena Petrenko has attempted to bring women to the forefront of the discussion on collaboration in an essay on female members of Organization of Ukrainian Nationalist (OUN) throughout 1930-1950. ${ }^{8}$ Petrenko's brief study confirms that women could be collaborators outside of the old notion of a "war wife" or prostitute and that

(Cambridge, Mass.: Harvard University Press, 2012), pp. 232-238; Helena Goscilo and Yana Hashamova (eds.), Embracing Arms. Cultural Representation of Slavic and Balkan Women in War (Budapest and New York: Central European University Press, 2012).

${ }^{5}$ Important literature on occupation policies includes Alexander Dallin, German Rule in Russia 1941-1946: a Study of occupation politics (Basingstoke: Macmillan, 1957); Timothy Mulligan, The Politics of Illusion and Empire: German Occupation Policy in the Soviet Union, 1942-1943 (New York: Praeger, 1988); T.J. Schulte, The German Army and Nazi Policies in Occupied Russia (Oxford; New York; Munich: Berg Publishers, 1989);

Alex J. Kay, Exploitation, resettlement, mass murder: political and economic planning for German occupation policy in the Soviet Union, 1940-1941 (New York: Berghahn Books, 2006) as well as Nazi policy on the Eastern front, 1941 Total War, Genocide, and Radicalization (Woodridge: Boydell \& Brewer, 2012).

On everyday life under occupation see Hiroaki Kuromiya, Freedom and Terror in the Donbas: A Ukrainian-

Russian Borderland, 1870-1990s (New York: Cambridge University Press, 1998), pp. 251-275.; Karel C. Berkhoff, Harvest of Despair: Life and Death in Ukraine under Nazi Rule (Cambridge, Mass.: Harvard University Press, 2004); Oleg V. Budnitskii (ed.), Odessa: Zhizn v okkupatsii. 1941-1944 (Moscow: ROSSPEN, 2013); Laurie Cohen, Smolensk under the Nazis: everyday life in occupied Russia (Rochester, NY: University of Rochester Press, 2013).

${ }^{6}$ Prominent literature on collaboration includes: Martin Dean, Collaboration in the Holocaust: Crimes of the local police in Belorussia and Ukraine (New York: St. Martin's Press in association with the United States Holocaust Memorial Museum, 1999);M. I. Semiriaga, Kollaboracionizm. Priroda, tipologia I proiavleniia $v$ gody Vtoroi Mirovoi Voiny (Moscow: ROSSPEN, 2000); Leonid Rein, The Kings and the Pawns: Collaboration in Byelorussia during World War II (New York: Berghahn Books, 2011); Mark Edele, Stalin's Defectors: How Red Army Soldiers became Hitler's Collaborators, 1941-1945 (Oxford: Oxford University Press, forthcoming 2017). For women as resisters, as members of partisan or counterinsurgency movements see Wendy Lower, Nazi Empire-building and the Holocaust in Ukraine (Chapel Hill: University of North Carolina Press, in association with the United States Holocaust Museum, 2005), pp. 190-193; Kenneth Slepyan, Stalin's Guerrillas: Soviet partisans in World War II (Lawrence: University Press of Kansas, 2006); A. Gogun, Staliniskii Kommandos. Ukrainskie partisanskie formirovaniya, 1941-1944 (Moscow: ROSSPEN, 2012).

${ }^{7}$ Peter Davies in Dangerous Liaisons: Collaboration and World War Two, (Harlow: Pearson Education, 2004) refers to women's relationship with the occupiers as "horizontal collaboration." In his expansive study on different forms of collaboration during the occupation Boris N. Kovalev discusses women only in the context of sexual relationships with the occupiers, see Kollaboratsionism v Rossii v 1941-1955 gg.: tipi i formi (Veliki Novgorod: NovGU imenia Yaroslava Mudrovo, 2009), pp. 348-365.

${ }^{8}$ Olena Petrenko, "Subektivnaia otvetstvinost:uchastie zhenschin v Organizatsii uktrainskikh natsionalistov I Ukrainskoi povstancheskoi armii (1930-1950 gg.)" in Oleg Budnitskii and Liudmila Novikova (eds.), SSSR vo vtoroi mirovoi voine: Occupatsia, Kholokost, Stalinizm (Moscow:ROSSPEN, 2014), pp. 134-148. 
they were not always coerced into the role but chose it for themselves. ${ }^{9}$ Wendy Lower's groundbreaking study on female perpetrators on the Eastern front, despite being based around German women, can be helpful in analysing Soviet female collaboration. Lower's study demonstrates that during the war some women voluntarily became witnesses, accomplices and even killers. These women came from diverse socio-economic background; they were influenced by ideology as well as careerism, greed, and desire to impress their superiors. "Hitler Furies" comprise a very small and extreme type of perpetrator, however, these women were not just cold-blooded psychopathic killers or unsympathetic witnesses; they were wives, mothers, and homemakers. ${ }^{10}$

Women who collaborated with the enemy under occupation were more than just "war wives" or prostitutes. ${ }^{11}$ They had varying and complex roles. Soviet women served as interpreters, bookkeepers, agricultural and factory workers, shopkeepers, spies and agents. Some remained married to their husbands while others formed new relationships with the occupiers. Some voluntarily collaborated while others were coerced or simply saw no other way out. When trying to explain why people actively perpetrated or collaborated in atrocities committed on the Eastern front, scholars have tried to point to an overarching motivating factor such as ideology, obedience to the authority, peer-pressure, or survival. This essay argues that there is no one stereotypical collaborator nor was there one dominant motivating factor for collaboration. The reasons for the women collaborators' actions during the occupation are as individual and varied as the women themselves.

\section{The Source-base}

According to the Russian Federal Security Services (FSB) during the years from 1943 to 1953, more than 320,000 Soviet citizens were arrested in the Soviet Union for collaborating with the enemy. ${ }^{12}$ The Soviet war crime trials of collaborators began in 1943 and continued well into the 1980s. Today the records from these trials remain in the former KGB archives located in the various post-Soviet states. Most of these trials were not public and many records were not available to academics until the United States Holocaust Memorial Museum in Washington D.C. acquired

\footnotetext{
${ }^{9}$ Other who have previously addressed the fact of women's participation in the OUN have focused on the sexual relations with the male members, see Marta Havryshko, "Illegitimate Sexual practices in the OUN underground and UPA in Western Ukraine in the 1940s and 1950s," The Journal of Power Institutions in PostSoviet Societies, no. 17, 2016, pp. 4214-1234.

${ }^{10}$ Wendy Lower, Hitler's Furies: German women in the Nazi killing fields (London: Chatto \& Windus, 2013).

${ }^{11}$ The notion that all women who remained under occupation and engaged in sexual relationships with the occupiers were viewed as collaborators by the Soviet authorities is incorrect. These women may have been vilified in the media and popular culture but they were not considered collaborators or traitors according to the Soviet law. I have found no cases where women were prosecuted for their involvement with the enemy without evidence of other crimes. For example in one of my cases defendant Poliakova-Garms was found guilty of collaboration because she worked for the SD as an interpreter and an agent, while her friend and codefendant llieva-Koropets, despite admitting to having sexual relationships with SD agents and policemen was found not guilty due to lack of any evidence of any criminal wrong doing. See USHMM, RG 31.018M, 11721 , reel 58, pp. 5265-5685.

${ }^{12}$ Tanja Penter, "Collaboration on Trial: New Source Material on Soviet Postwar trials against Collaborators", Slavic Review, vol.64, no.4, 2005, p. 783.
} 
microfilm copies of a large number of them. The collection consists of thousands of trials for collaboration from the Baltic States, Ukraine, Moldova, Uzbekistan, Kazakhstan and Russia. The files consist of interrogation records, testimonies of witnesses and defendants, court proceedings, final sentencing and in some cases applications for rehabilitation. The trial records provide extensive biographical background on the defendants. For my study I had chosen one particular collection, the "Trials related to the Holocaust." ${ }^{13}$ The trials all took placed in occupied Ukraine. The collection contains just over 820 individual cases; however, there are over a thousand individuals on trial as many cases include multiple defendants. By isolating those collaborators who held civilian positions before the war and compiling a database I was able to identify a notable group of female collaborators. It is upon these women's trial records that I have based my research.

The Post-war Soviet war crime trials are still a relatively new source base for academics but those who have worked with the records have found them to be trustworthy and useful. ${ }^{14}$ Soviet primary documents do pose a range of problems for scholars, particularly if the official documents such as these trial records are to be viewed through the prism of the Great Terror and the show trials of the 1930s. Alexander Prusin, in his analysis of the Soviet post-war crime trials, has demonstrated that the Soviet criminal justice system had undergone changes throughout the 1940s and that the post-war trials were, in fact, conducted according to the judicial norms of the time.${ }^{15} \mathrm{He}$ also points out that coercion and fabrication of evidence was often not needed in the immediate aftermath of the war as "traces of German crimes in the Soviet Union were visible, widely known, and undeniable." ${ }^{16}$ In my own research I had found the existence of cases where the defendants were found not guilty of their charges due to a lack of evidence which suggests a high degree of legitimacy in the investigative and judicial processes represented in these documents. ${ }^{17}$ Diana Dumitru has further demonstrated the reliability of the sources by triangulating the information presented in the documents with evidence found in other sources such as oral histories. ${ }^{18}$ The trail records as primary sources are not without their limitations; however, they should not be dismissed as useful as they provide vital evidence and details about the occupiers, the civilians, as well as the violence that took place under the occupation between 1941 and 1945.

\footnotetext{
${ }^{13}$ USHMM, RG 31.018M.

${ }^{14}$ David Alan Rich, "Reinhard's Footsoldiers: Soviet trophy documents and investigative records as sources," in John K. Roth and Elisabeth Maxwell (eds.), Remembering for the future: The Holocaust in an Age of Genocide, vol. 1 (New York: Pelgrave, 2001), pp. 688-701; Tanja Penter, "Collaboration on trial: new Source Material o Soviet Postwar Trials against Collaborators", Slavic Review, vol. 64, no. 4,pp. 782-790; Tanja Penter, "Soviet war crimes trials under Stalin (1943-1953)," Cahiers du monde russe, vol. 49, no. 2, 2008, pp. 341-364; Diana Dumitru, "An Analysis of Soviet Postwar investigation and Trial Documents and their relevance for Holocaust Studies," in Alexander M. Martin, Tarik Cyril Amar, Michael David-Fox and Peter Holquist (eds.), The Holocaust in the East: Local perpetrators and Soviet responses (Pittsburgh: University of Pittsburgh Press, 2014), pp. 142157.

${ }^{15}$ Alexander Prusin, “'Fascist Criminals to the Gallows!': The Holocaust and Soviet War Crimes Trials, December 1945-february 1946”, Holocaust and Genocide Studies, vol. 17, no. 1, 2003, pp. 1-30.

${ }^{16}$ Ibid., p. 17.

${ }^{17}$ See USHMM RG 31.018M, 8489, reel 52, pp. 58862-59371, and case 6567, reel 57, pp. 3484-3729.

${ }^{18}$ Dumitru, 2014.
} 


\section{Women Collaborators}

From over 800 cases and over a thousand of individuals in the collection I have identified some two hundred civilian collaborators. Around fifteen percent of these were female. Twenty four out of the twenty nine cases involving women collaborators in this particular collection took place in Crimea. ${ }^{19}$ The remaining trials occurred in other regions of Soviet Ukraine such as Sumy, Vinnitsa, Donbas, Zaporozhe and Cherkasy. Out of the twenty-nine females seven were Russian, four Ukrainian, three Greek, two German, a Tatar, a Bulgarian and the rest unknown. At least twelve of the women in question were under the age of thirty when the war broke out in 1941. The youngest was seventeen and the oldest forty seven. About half were married before or during the war while the others were single or widowed. Roughly half of the women had children. Three of the women were members of the Communist Party. One woman came from an aristocratic background and another's family underwent dekulakization in 1929. Some peasant women had minimal education but the majority of defendants were well educated and literate. None of the defendants had any history of anti-Soviet agitation or other criminal records. A few were part of the Soviet partisan movement until their capture. The crimes these women committed during the German occupation ranged from denunciation, to helping the occupation regime through administrative work, to actively being an agent provocateur and a spy. All but one was found guilty and convicted of their crimes.

\section{Soviet female defendants tried for collaboration in Occupied Ukraine}

\begin{tabular}{|c|c|c|c|c|c|}
\hline \multicolumn{2}{|l|}{ Categories } & \multirow{2}{*}{$\frac{\#}{5}$} & \multirow{2}{*}{$\frac{\%}{17.2}$} & \multicolumn{2}{|c|}{ Total: } \\
\hline \multirow[t]{6}{*}{ Age } & $<20$ & & & \multirow{6}{*}{29} & \multirow{6}{*}{$100 \%$} \\
\hline & $20-29$ & 7 & 24.1 & & \\
\hline & $30-39$ & 5 & 17.2 & & \\
\hline & $40-49$ & 1 & 3.5 & & \\
\hline & $50+$ & - & - & & \\
\hline & No data & 11 & 38 & & \\
\hline \multirow[t]{5}{*}{ Nationality } & Ukrainian & 4 & 13.8 & \multirow{5}{*}{29} & \multirow{5}{*}{$100 \%$} \\
\hline & Russian & 7 & 24.1 & & \\
\hline & German & 2 & 6.9 & & \\
\hline & Other & 5 & 17.2 & & \\
\hline & No data & 11 & 38 & & \\
\hline \multirow[t]{4}{*}{ Education } & Elementary & 3 & 10.3 & \multirow{4}{*}{29} & \multirow{4}{*}{$100 \%$} \\
\hline & Middle & 8 & 27.6 & & \\
\hline & Higher & 7 & 24.1 & & \\
\hline & No data & 11 & 38 & & \\
\hline \multirow{4}{*}{$\begin{array}{l}\text { Familial Social } \\
\text { Background }\end{array}$} & Nobility & 1 & 3.5 & \multirow{4}{*}{29} & \multirow{4}{*}{$100 \%$} \\
\hline & Kulak & 1 & 3.5 & & \\
\hline & Other & 16 & 55 & & \\
\hline & No data & 11 & 38 & & \\
\hline
\end{tabular}

\footnotetext{
${ }^{19}$ It is not clear why the majority of the women defendants are found in Crimea as the contents of the postwar crime trial collections were often selected at ad hoc, but perhaps the evidence found by the post-war investigators of the Simferopol occupation administration lead them to the large cohort of Soviet collaborators.
} 


\begin{tabular}{|c|c|c|c|c|c|}
\hline \multirow{4}{*}{$\begin{array}{l}\text { Political } \\
\text { Affiliation }\end{array}$} & Communist Party & 3 & 10.3 & \multirow{4}{*}{29} & \multirow{4}{*}{$100 \%$} \\
\hline & OUN & - & - & & \\
\hline & None & 15 & 51.7 & & \\
\hline & No data & 11 & 38 & & \\
\hline \multirow{5}{*}{$\begin{array}{l}\text { Wartime } \\
\text { Service }\end{array}$} & Red Army Combatant & - & - & \multirow{5}{*}{29} & \multirow{5}{*}{$100 \%$} \\
\hline & NKVD agent & 1 & 3.5 & & \\
\hline & Partisan & 1 & 3.5 & & \\
\hline & None & 16 & 55 & & \\
\hline & No data & 11 & 38 & & \\
\hline \multicolumn{6}{|c|}{$\begin{array}{l}\text { The above data was collected from the trial records housed in the collection RG- } \\
\text { 31.018M, Postwar war crimes trials related to the Holocaust, United States Holocaust } \\
\text { Memorial Museum Archives, Washington, DC. }\end{array}$} \\
\hline
\end{tabular}

\section{Simferopol, Crimea.}

Out of the twenty nine cases in the sample, twenty four took place in Crimea, and fourteen of these took place in the city of Simferopol. In all fourteen cases the female collaborators had dealings with the Simferopol Nazi Security Service (SD) in some capacity. Four of the defendants Emilia Berikova, Maria Poliakova-Garms, Maria Epp, and Tatiana Matchenbaeva worked as interpreters for the Simferopol SD. The four women were tried at different times and had minimal relation, although they testified at other's trials, confirming each other's' presence and activities at the SD. Other women found themselves working as agents in the SD prison, on the streets and in their own apartment buildings. Even though most of the women were tried separately it makes sense to compare and contrast the women's biographies and careers while working with the occupiers in order to understand the circumstances under which women collaborated. ${ }^{20}$

Emilia Berikova was a single, educated, nineteen year old Tatar girl, member of the All-Union Leninist Communist League of Youth (VLKSM) who worked as an accountant for the Communist Party before the occupation. Tatiana Matchenbaeva was a Russian, thirty eight year old widow with children who worked odd jobs before the war broke out, she was literate and had typing skills. She was highly respected at the SD because of her noble family background and her fluent German and French. Both Maria Epp and Maria Poliakova-Garms were of ethnic German background which is why the German occupation regime targeted them for recruitment. Not only did the Nazi ideology dictate that Germans were of superior race, but ethnic Germans were also useful for more pragmatic reasons: as translators, administrative workers, typists etc. Epp testified that she fluently spoke Russian, German, Ukrainian, English and Spanish. She was highly educated; in 1936 she graduated from an agricultural and veterinary institute and in 1941 she completed a foreign languages degree majoring in English. Epp was twenty four and single at the time of the occupation.

\footnotetext{
${ }^{20}$ Case file for Emilia Berikova can be found in USHMM, RG 31.018M, 8801, reel 57, pp. 4030-4089. Maria Poliakova-Garms, USHMM, RG 31.018M, 11721, reel 58, pp. 5265-5685. Maria Epp, USHMM, RG 31.018M, 10925, reel 58, pp. 4438-4750. Tatiana Matchenbaeva, USHMM, RG 31.018M, 97881, reel 58, pp. 4787-5264.
} 
Maria Poliakova-Garms was thirty four, a Communist from a peasant family with seven years of schooling. Her husband was mobilized into the Red Army in 1941. They had two children. The four women were all recruited to work for the SD in administrative positions between 1941 and 1943. The four women had different ethnic, socio-economic and family backgrounds; all they had in common was their ability to speak German.

Not everybody who worked for the SD did so in an official administrative capacity. SD bosses would sometimes recruit spies and agents from amongst the prisoners. Four of the defendants, ended up in the SD prison at some point between 1941 and 1943: nineteen year old Ukrainian Maria Yablokova, eighteen year old Russian (from a German father) Olga Fink, seventeen year old Russian Tatiana Taranova and Maria Trubach, twenty seven year old Russian. Both Yablokova and Fink were placed in the SD prison as agents. Taranova was arrested for being a partisan and held for over a year in prison until finally being approached about working for the Germans in exchange for release. Trubach had a very brief stint in prison and was approached by the SD upon release from prison. ${ }^{21}$

Outside of the Simforopol SD cohort women collaborators held a number of civilian positions. In Stalino (now Donetsk), nineteen year old Ukrainian Tatiana Teplinskaya worked for the local Police Headquarters as a passport officer. In the city of Romny, Sumy region forty-seven year old Russian Elena Zelenskaya worked as the Housing Commissioner. In Evpatori, Crimea twenty nine year old Ukrainian widow Tatiana Koroleva worked at a local cotton factory. Some women continued to be employed in the same capacity as they were before the occupation. In village Tishi, Saky oblast of Crimea Bulgarian thirty-seven year old Tamara Neikova worked at a dairy factory. In a small Crimean village Tuzli a twenty nine year old Russian Tatiana Melnik proceeded to work on the same collective farm throughout the occupation. Komsomolka Tatiana Krakashova continued to work as a brigadier of an all-woman team of kolkhoz workers. Some, such as Feodora Tuttuninkova, did not hold a position with the occupying forces at all. Not all women collaborators worked for the occupation administration directly, but they did assist the enemy in one way or another. Those that were not directly involved in the administration were often found guilty of denouncing on local Jews or partisans. ${ }^{22}$

\section{Recruitment}

\footnotetext{
${ }^{21}$ Maria Yablokova's, USHMM, RG 31.018M , 9903, reel 58, pp. 5685-5978.

Olga Fink, USHMM, RG 31.018M , 11881, reel 57, pp. 2325-2650.

Tatiana Taranova and Tatiana Trubach, USHMM, RG 31.018M, 13619, reel 56, pp. 456-1833.

${ }^{22}$ Tatiana Teplinskaya, USHMM, RG 31.018M, 57803, reel 53-54, pp. 9374-9478.

Elena Zelenskaya, USHMM, RG 31.018M, 4894, reel 86, pp. 1052-1185.

Tatiana Koroleva, USHMM, RG 31.018M, 6919, reel 77, pp. 21254-21300.

Tamara Neikova, USHMM, RG 31.018M, 7588, reel 57, pp. 4090-4230.

Tatiana Melnik, USHMM, RG 31.018M, 8828, reel 57, pp. 4299-4344.

Tatiana Krakashova, USHMM, RG 31.018M, 8377, reel 57, pp. 3730-3923.

Feodora Tuttuninkova, USHMM, RG 31.018M, 15498, reel 90, pp. 9741-9861.
} 
Maria Epp began her employment with the German occupying forces in the Melitopol SD in December 1941, however, three weeks later the region was taken back by the Soviets and she was taken prisoner. In January 1942 the city was a battlefield, the prison was left virtually unattended and most prisoners escaped. She was swiftly arrested by the Germans under suspicion of being a Soviet spy but was later released and recruited to work for the Simferopol SD. ${ }^{23}$

Before the war broke out, Maria Poliakova-Garms seemed to be a good Soviet citizen. In 1932 she completed a course for Komsomol Administrative Staff in Simferopol. While studying she was elected starshina (head) of her class and the deputy secretary of the Komsomol collective. She finished her course with the highest grades and in 1932 joined the Communist Party. In 1934 she was sent to study at the agricultural school, and then from 1936 until the occupation she worked as an administrator for various government agencies. Despite her seemingly perfect Soviet biography, Maria was the first out of the four defendants to join the ranks of the Simferopol SD. A neighbour who knew Maria before the war testified that in 1941 she purposefully evaded Soviet authorities and evacuation from Crimea by hiding out at her friend's apartment. ${ }^{24}$ The Soviet authorities wanted to evacuate Poliakova-Garms, not only because she was a party member but also because she was an ethnic German, an alleged security threat. ${ }^{25}$ The authorities were right to be worried about Poliakova-Garms' loyalties because one eyewitness testified that just two days after the Germans came to Simferopol Poliakova-Garms showed up, along with her two children, at the administration office, told them she was German and asked for a job. ${ }^{26}$

Out of all the defendants on trial, Tatiana Matchenbaeva had the strongest reasons for hating Soviet authorities, yet her life and actions prior to the outbreak of war show no signs of outright discontent with the Soviet authority. Matchenbaeva came from a wealthy aristocratic background. In 1918 all the family property was nationalized. Her father died that same year. In 1921 the whole family was arrested under suspicion of involvement with an underground counterrevolutionary group, but released due to a lack of evidence. In 1937 her husband was arrested by the NKVD and charged with "wrecking" under the criminal code 58-7. ${ }^{27}$ He died fourteen months into his sentence from dysentery. In 1938 her sister's husband was also arrested by the

\footnotetext{
${ }^{23}$ All of this information was given during an interrogation on $2^{\text {nd }}$ of October 1952, USHMM, RG 31.018M, 10925, reel 58, pp. 99-108.

${ }^{24}$ USHMM, RG 31.018M, 11721, reel 58, p. 5679.

${ }^{25}$ Soviet "civilians figured into the evacuation only insofar as they were necessary to the war effort" so the categories of people to be evacuated on first priority were "qualified workers, engineers, and employees with enterprises evacuated from the front; the population, in which first place youth fit for military service; Soviet and party leadership cadres." see Manley, 2009, p. 34.

Ethnic minorities including Germans, Tatars, Greeks, Finns etc. were considered security threats and also evacuated early on in the war. According to Polian's calculations around 53000 ethnic Germans were deported from Crimean ASSR in August of 1941. See Against their will, 2004, p. 330.

${ }^{26}$ USHMM, RG 31.018M, 11721, reel 58, pp. 5265-5685.

${ }^{27}$ Article 58 of the penal code was put in force in 1927. The article cover all counter-revolutionary offences; section 58-7 addresses individuals dubbed "wreckers", people who undermined state industry, transportation, trade, monetary relations as well as cooperative societies or organizations with counterrevolutionary purposes.
} 
NKVD and was released in 1941. In the same year her cousin was arrested and sentenced to five years in labour camps.

Despite all the repressions and suspicions from the Soviet authorities towards her family, Matchenbaeva remained a hard working young woman and active member of Soviet Society. ${ }^{28}$ After her father's death in 1921 she entered the workforce. In 1945 she admitted that as an adult she began hiding her family background in job application because she was often turned down if the prospective employers found out she came from the nobility. Such "masking" was quiet typical: "Recounting of one's biography ... and defence of it became a standard Soviet practice in a variety of situations", writes Fitzpatrick. "It was obviously in the interest of the individuals to compose an autobiography that concealed 'bad' class backgrounds." ${ }^{29}$ With the help of her uncle who held a high ranking position in the Red Army, Matchenbaeva got her first job as a journalist at an army base. In 1931 Tatiana married her second husband Marchenbaev, and they moved to Crimea. While in Crimea she held a job in the human resources department of a wine factory "Massandri" and also served as chairman of the local Mestkom (trade union committee).

Matchenbaeva and her son planned on evacuating when the Germans came but were told that all factory employees were last on the evacuation list. Much of the Crimean population did not manage to evacuate as "priorities were structured around the military and industrial needs of the state as well as pre-war hierarchy of people and places," so being lowly administrator did not automatically qualify Matchenbaeva for evacuation. ${ }^{30}$ She testified that she had met a Red Army Captain in August of 1941 who promised to come back and help her evacuate, but he never returned. ${ }^{31}$ Considering Manley's argument that "as civilians, women were thus subject to evacuation only in their capacity as mothers, and, in the case of the party, soviet, and army officials, as wives" Matchenbaeva's statement sounds plausible. Perhaps if the Red Army Captain had indeed come back for her and evacuated her as his significant other her fate might have been very different.

In December 1941 Matchenbaeva's brother was arrested by the SD under suspicion of being a partisan. Matchenbaeva testified that he indeed was part of a partisan battalion but he deserted and came home. ${ }^{32}$ Defendant Poliakova-Garms testified that she had known Matchenbaeva before

\footnotetext{
${ }^{28}$ On life of "former people" under Soviet Rule see Golfo Alexopolous, Stalin's Outcasts: aliens, citizens and the Soviet state, 1926-1936 (Ithaca: Cornell University Press, 2003) and Douglas Smith, Former People: The last days of the Russian aristocracy (London: Pan Books, 2013).

${ }^{29}$ Fitzpatrick, 2005, p. 5.

${ }^{30}$ Manley, 2009, p. 33. Besides the "useful" population such as youth for military service other people in privileged positions such as Intelligentsia and Communist party cadres as well as their families and families of Navy, Red Army and NKVD commanding personnel were included in the initial evacuations from the front zone, p. 35.

${ }^{31}$ Ibid, p. 38.

${ }^{32}$ Gogun had compiled a table of partisan personnel makeup between 1941-1944 which totaled at 45478 individuals, including a number of those that had deserted as being 343 . Overall numbers of partisans including detachments is not known but estimated at 115000 , and total number of those that defected is also not known. P. 329, p.342.
} 
the war and that she recognized her often coming to the SD and pleading on behalf of her brother. ${ }^{33}$ Thanks to her persistence and connections with Poliakova-Garms, Matchebaeva's brother was released. After hearing about her past an SD officer, Dr. Braun, offered Tatiana a job. On 19 February 1942 she reported for her first day at the SD. When asked by the Soviet investigators in 1945 why she had volunteered she said it was Dr. Braun's pleasant treatment of her that persuaded her to work for them, however, if her brother hadn't been arrested she might not have come in contact with SD at all. ${ }^{34}$

The Tatar girl, Emilia Berikova, often had to support herself and her parents financially throughout the war. She entered the workforce straight after school graduation and became a bookkeeper for the Communist party. When the occupation began in October of 1941 her department was told, just like Matchenbaeva, that they were the last on the evacuation list. When she came to work on the 31 of October much to her surprise everybody was gone. They had evacuated without her. According to the contemporary reports this was not uncommon as evacuations were poorly organized and many people self-evacuated in panic. ${ }^{35}$ Berikova remained with her parents and unemployed until April 1942. In order to avoid deportation to Germany Berikova tried to find any kind of employment in the region. Despite the German propaganda encouraging volunteers for work in the Reich word about the working conditions quickly spread in the East. Rumours of forced sterilization, women being sold into brothels and poor treatment of workers terrified the locals. ${ }^{36}$ Luckily Berikova found a job as a bookkeeper at the local agricultural administration through an accountant friend of hers. In March 1943 she was sent to work in the same capacity in a different town but she quit her job in June under the pretences that her mother was sick. According to Berikova the Germans had stopped forcefully sending people from the region to work in Germany by 1943 so she felt safe living at home with her parents. Her father owned a small repair shop that was making enough money at that point to support the family.

Berikova's unemployment only lasted a couple of months as by August 1943 she was recruited to work for the SD. She was targeted for recruitment by the chairman of the local Muslim Committee. One day she ran into him on the street and he began persuading her to apply for a job at the SD. Beriakova declined; "I told him that at this time I did not intend to work for them, I did not give him a definite 'no' but I just said that at the moment I was not in need of employment." ${ }^{37} \mathrm{~A}$ few days later the Chairman summoned her to his office. At the meeting he began to persuade her again, and yet again she said she did not need a job. Despite her passive attempts to reject the offers, she was left with no choice as the next day an Unterscharführer (junior squad leader) of SD came to her apartment and demanded she go to the Labour Department offices and register for employment.

\footnotetext{
${ }^{33}$ See Poliakova-Garms testimony in the final protocol in USHMM, RG 31.018M, 97881, reel 58, p. 5256.

${ }^{34}$ Ibid., pp. 5256-5264.

${ }^{35}$ Manley, 2009, p. 51-53.

${ }^{36}$ Berkhoff, 2004, p. 258.

${ }^{37}$ Ibid.
} 
By her own account, Berikova resisted collaborating until she had no other choice. For others, collaborating was their only way out of a bleak situation. Women under suspicion of partisan involvement captured by the occupiers faced a choice between collaboration and death. In return for freedom prisoners were asked to give information and often help in finding and apprehending other operatives in the area. At the time of her arrest Yablokova was an NKVD trained radiooperator and Taranova was a partisan on a mission. Yablokova came from kulak background; her entire family underwent dekulakization in 1929. She became a widow at a young age of eighteen when her husband was killed at the front in 1941. That same year she was recruited by the NKVD and undertook courses in radio transmission. The way she describes this event appear as if she had no real motivation to join the NKVD, but that she was offered little alternative by the recruiting officer. ${ }^{38}$ When the occupation began she had orders to remain in an apartment in Sevastopol with a radio, codes and documents. When the occupation forces marched in she made no attempts to carry out her mission. For weeks she evaded the occupiers until a local policeman noticed her sneaking in and out of the building. Once apprehended, Yablokova gave up all information regarding her training, teachers, handlers and other agents.

Tatiana Taranova's story appears to begin and end the same as Yablokova's: recruited into Soviet counterintelligence, left behind enemy lines, arrested by the occupying forces and forced to denounce fellow partisans. Yet there are some obvious differences between the two. Taranova came from a poor peasant not a kulak background. Before the war she worked as a bookkeeper for the kolkhoz. When the war broke out she volunteered to be part of a partisan unit. According to 1943 reports by Soviet officials many peasant women were desperately trying to join the partisans in order to avoid forced labour in Germany. ${ }^{39}$ Despite official propaganda's encouragement of women's participation in partisan movements women were still, more often than not, relegated to support roles. ${ }^{40}$ Initially, Taranova also worked as a cook in the field kitchen, but on the 4 of August 1942 she, along with two others, was sent on a mission to collect intelligence. Women were rarely sent into combat missions except as couriers, spies or agitators "which took advantage of the occupier's leniency toward traveling women." ${ }^{41}$ On their journey they stopped in her home village of Petrovka, but a local policeman recognised her and gave her up to the police. She was sent to the Simferopol SD prison where she remained for over a year. In 1943 she was called upon to serve as a spy in return for freedom. She was warned that if she refused she would be shot. ${ }^{42}$ Unlike Yablokova, Taranova volunteered to serve in the partisans, she had intentions of carrying out her mission, and she spent a year in prison which implies her reluctance to cooperate. But in the end she succumbed to the inevitability of her situation.

Like Taranova, Maria Trubach came from a poor peasant background, and like Yablokova her husband was mobilised into the Red Army. Just like the other two women, Trubach was arrested by

\footnotetext{
38 USHMM, RG 31.018M, 9003, reel 58, pp. 5691-5695.

${ }^{39}$ Slepyan, 2006, p. 201.

${ }^{40}$ Ibid, p. 202.

${ }^{41}$ Ibid, p. 195.

${ }^{42}$ USHMM, RG 31.018M, 13619, reel 56, p. 753-756.
} 
the SD in 1942. However, she was not a Soviet partisan or involved with any counterintelligence services. She was arrested due to a letter of complaint that came from another woman she was feuding with. Upon investigation Trubach was released and hired as a cleaner at the SS headquarters. One day she was summoned to the SD and asked to denounce on citizens in Simferopol. Prior to her arrest she had worked for the Geheime Feldpolizei (Secret Field Police) and this may have been why she was approached by the SD. ${ }^{43}$

\section{On the Job}

Working as interpreters for the SD required the women to take part in searches, arrests and interrogations of suspects. Matchenbaeva played a big role the apprehension of 500 suspected members of counterinsurgency groups from Simferopol and Feodosia. Poliakova-Garms was connected to an SD operation that resulted in the murder of 425 sick, elderly and mentally ill patients of the Simferopol Mental Institution. The massacre took place on 7 of March 1942. All the victims were gassed. Poliakova-Garms' job was to help translate during the operation as well as question medical staff of the institution afterwards. ${ }^{44}$ Apparently Poliakova-Garms also liked to beat suspects and pose for photographs with them. ${ }^{45}$ She admitted that rubber batons were regularly used during interrogations. ${ }^{46}$ She quit her job as an interpreter for the SD in February 1943 and between then and her evacuation in 1944 she and another woman, llieva-Koropets owned a fruit and vegetable shop that served as a rendezvous place for Nazi agents. ${ }^{47}$ The least enthusiastic collaborator of the four interpreters, Beriakova, also had the least influential position in the SD. She was asked to translate newspaper articles and reports from Tatar to German. She never took active part in interrogations or arrests like the others. She attended an interrogation once and only because the man asked for a Tatar interpreter as he did not speak Russian or German very well. ${ }^{48}$

The agents and spies recruited by the SD were often, like Yablokova and Fink, placed into prison cells to eaves drop or even provoke other inmates into giving out information. Matchanbaeva confirmed that while working for the SD in November 1942 she saw Yablokova arrive with a group of prisoners. ${ }^{49}$ Shortly thereafter she saw a letter from the authorities confirming that Yablokova was working as an agent inside the prison. Upon release Yablokova worked as a spy on the outside. According to witness testimonies Yablokova often went on investigation with SD officers out of town. She was responsible for an outing of a partisan group who were all later shot. According to the findings of the Soviet investigators she was present at this mass shooting. ${ }^{50}$

\footnotetext{
43 Ibid, pp. 718-724.

${ }^{44}$ Ibid, p. 1325.

${ }^{45}$ Ibid, p. 1269.

${ }^{46}$ Ibid.

${ }^{47}$ Ilieva-Koropets was tried along with Poliakova-Garms but was found not guilty of collaboration due to a lack of sufficient evidence.

${ }^{48}$ USHMM, RG 31.018M, 8801, reel 57, pp. 4086-4089.

${ }^{49}$ Matchenbayeva gave testimony in Yablokova's investigation. See USHMM, RG 31.018M, 9903, reel 58, pp. 5975-5976.

50 lbid., p. 5978.
} 
Trubach was approached by the SD to serve as an agent. She was given a simple mission of going to an apartment in order to find out if a woman suspected of harbouring partisans lived there. She went to the apartment but accidentally got the house number wrong and wound up in the military administration building where she was swiftly detained as she had no papers. After this blunder she claims she never received any more orders, but the investigation showed that she had received orders to spy on civilians. She denounced a couple she had befriended before the recruitment as an agent. During a conversation over dinner and drinks at the couple's house the wife spoke out against Hitler: she had worked at the Simferopol Mental Institution and saw first-hand Nazi officers taking patients into the gas vans. ${ }^{51}$ Upon relaying this information to the SD officer Trubach was told to continue her work. During another evening of drinking the husband let it slip that he had friends in a nearby village that could get him to the nearest partisan unit. Not long after the SD arrested and shot the trio. According to the investigation Trubach had also denounced many others, including Jews and even her own sister. When asked why she said "I was an agent and so it was my job." ${ }^{52}$

Feodora Tuttuninkova, a Greek widow with two children from a poor peasant background managed to live through the occupation unemployed by aligning herself intimately with the occupying forces. She cohabited with a Romanian soldier in Simferopol who moved her, her sister and children into a large apartment vacated by Jews. The Jewish population of Simferopol was temporarily ghettoized on one street in the city; they were later killed. According to the neighbours she went around the other vacated apartments and took whatever property she wanted. A neighbour testified that she walked past Tuttuninkova's apartment one day and noticed that she had new curtains and table cloths. Merely possessing Jewish property did not amount to collaboration, what happened after the woman's arrival in the apartment building secured her fate a collaborator. ${ }^{53}$ At least eleven Jews that lived in the building were hiding out in the attic. One day Tuttuninkova's son saw one of them climbing out and told his mother. The man pleaded with Tuttuninkova. He offered money but she refused and denounced them all to her boyfriend. All the Jews were arrested. A neighbour said she saw the police officers move all the Jewish property from the attic and into Tuttuninkova's apartment. Some neighbours said they overhead Tuttuninkova speak ill of Jews, while another said she expressed fear that if did not denounce she herself would be punished. ${ }^{54}$

\section{Benefits of employment}

\footnotetext{
${ }^{51}$ USHMM, RG 31.018M, 13619, reel 56, p. pp. 718-724.

52 Ibid.

${ }^{53}$ USHMM, RG 31.018M, 15498, reel 90, pp. 9858-9861.

${ }^{54}$ Ibid.
} 
One motivation that seems to apply to many women collaborators was one of financial stability and improving their living conditions. Work was a necessity for many women in Soviet Union, and war did not change that. If the place of employment was still functioning after the occupation the employees remained there. If the place of employment was destroyed or dissolved then the workers had to find new ways of earning a living. If young people were unemployed in the occupied territories the administration would send them to Germany to work. Beriakova was threatened with forced labour but due to luck and resourcefulness she managed to find a job and remain in Crimea with her parents. Some people had to work wherever the occupation labour department sent them. Trubach who was working as a cleaner jumped at the opportunity to work for the SD as an agent. As her first payment Trubach was given a bottle of oil, a bottle of vodka and three kilograms of flour. ${ }^{55}$ After her blunder with the first mission she looked for an opportunity to remain in the official's good graces. In order to redeem herself she denounced and spied on civilians.

"For those who were eligible and willing to take them," Lower points out, "the jobs in the German administration seemed to be the best." ${ }^{56}$ Not only were the working conditions better but often administrative jobs provided opportunities for material enrichment outside the monthly wage. Zelenskaya, for example, worked for the Housing Commission which gave her access to vacated apartments and the property inside them. Employment at the SD came with benefits such as meals at the cafeteria. "Even the lower-level office jobs paid at least double the monthly wage of a factory worker or agricultural labourer." ${ }^{57}$ Beriakova said she was paid 600 roubles a month to work as an interpreter. Matchebayeva had a salary of 1000 roubles a month, which was on par with some raion leaders' monthly wages. ${ }^{58}$ The difference in the two women's pay can be attributed to the fact the Matchebayeva's job was of greater importance to the administration. The fact that her boss was in love with her also played a significant role. The ability to form personal relationships with the administrators was of great benefit to women trying to make ends meet under occupation.

Just as Lower's furies "attached themselves to men of power and in turn wielded considerable power themselves", so did some of the Soviet women under occupation. ${ }^{59}$ Working in close proximity with the occupying forces often came with opportunities for personal advancement through close relationships. Poliakova-Garms had "intimate relationships" with a number of SD officers. ${ }^{60}$ She received an apartment from the administration, which was later upgraded to a fivebedroom home. Rein has noted that even though the official allocation of housing was meant to be prioritised according to need (refugees or people whose houses were destroyed), in reality

\footnotetext{
${ }^{55}$ USHMM, RG 31.018M, 13619, reel 56, pp. 718-724.

${ }^{56}$ Lower, 2004, p. 51.

${ }^{57}$ Ibid.

${ }^{58}$ Raion leaders were getting between 1000 and 3000 roubles a month. Lower also notes that these wages were higher than what the Soviets paid in the 30s; a Soviet raion leader only received 750 roubles a month, see Nazi Empire Building, 2005, p. 51 as well as foot note 29 on p. 224.

${ }^{59}$ Lower, 2013, p. 5.

${ }^{60}$ USHMM, RG 31.018M, 11721, reel 58, p. 5622. The other two officers named Bruker and Balter. She also went to arrests and shootings with them.
} 
"protectionism and nepotism were often the only criteria for the allocation of the living quarters." ${ }^{61}$ Through friends with the administration women could receive a new dwelling or other luxury items. Matchenbayeva also admitted to being in close relationship with the German officers and that she could influence some of their decision-making. Witnesses testified that she and others at the office could help free prisoners for a bribe of gold coins. Other forms of material gain came from confiscated property. A witness claims that Epp collected some prisoner's private property and kept it for herself. Poliakova-Garms also helped herself and her friends to confiscated property such as furs, gold and other luxury items. ${ }^{62}$

Matchenbayeva claimed to not have had any intimate relations with the officers, but there were some who did. Poliakova-Garms admitted to sleeping with a number of SD officers, in fact her and a friend often hosted "parties" for the German officers at their home. Taisia Koroleva, a poor factory worker, entered into a relationship with an ethnic Russian SD agent in return for a place to live and financial support. She later found out he was an intelligence agent when he asked her to spy for him. Greek widow Tuttuninkova lived in Simferopol with a Romanian soldier. Neighbours said she went around the apartment building proclaiming "I work for the Gestapo, and everything here belongs to me." ${ }^{63}$ Investigation showed she was not employed by the administration; it was her relationship with the solider that, in her eyes, made her powerful.

Tuttuninkova's relationship with the Romanian soldier elevated her from a poor peasant widow to a well off lady of the house. Many neighbours were witness to her shameless antics when she went around to all the Jewish apartments and took whatever property she wanted. ${ }^{64}$ According to one neighbour, Tuttuninkova borrowed a gramophone from her and when she asked for it back Tuttuninkova proclaimed "this used to belong to a Jew, ... all Jewish property is now Gestapo's property!" ${ }^{65}$ Her behaviour resembled that of some of Lower's furies;

Wives of top officials paraded around in stolen furs and demanded superior living quarters, ordering Jewish craftsmen to lay stolen porcelain tiles in lavish bathrooms and to erect custom-made balconies. ${ }^{66}$

These women not only enjoyed the material wealth that came with their situation but also the power that their position yielded. In his analysis of collaboration in Belorussia Rein argues that those in position of authority often became "intoxicated with power." Similarly Tuttuninkova went from a poor widow and shopkeeper under the Soviet rule to a woman taken care of by a man with power and means. In the Stalinist 30's the possibility of upward mobility became a common rhetoric, yet it was not until occupation by the Germans that women like Tuttuninkova and Poliakova-Garms

\footnotetext{
${ }^{61}$ Rein, 2011, p. 275.

${ }^{62}$ For a broader discussion of Jewish property confiscation by the occupiers see Martin Dean, Robbing the Jews: the Confiscation of Jewish property in the Holocaust, 1933-1945 (Cambridge: Cambridge University Press, 2008).

${ }^{63}$ USHMM, RG 31.018M, 15498, reel 90, p. 9856.

${ }^{64}$ Ibid, pp. 9857-9858.

65 Ibid.

${ }^{66}$ Lower, 2013, p. 102.
} 
were able to improve their social status. ${ }^{67}$ They finally had power and they yielded it in the few ways they could, by sealing the Jew's fates and taking their stuff in the process.

\section{Denunciations}

Just as working in an official capacity offered material rewards, so did denunciations. "The desire to take possession of the Jew's property undoubtedly influenced the attitude of the local population to various anti-Jewish measures." ${ }^{\prime 68}$ Tuttuninkova denounced the Jews hiding out in the attic because she benefited from their vacated apartment and the abandoned property. If the Jews were not arrested they would have fled and taken their property with them. Matchanbayeva confirmed that in 1942 she and Epp went to a Jewish woman's apartment and brought back two suitcases of stuff which they later distributed amongst themselves. Women's interests in "things" can be traced back to the 1930s when receiving luxury items were used as incentives for hard work in Soviet Union, and the same patterns were recreated by these women under occupation. ${ }^{69}$

In her study of Zhytomyr under Nazi occupation Lower found that several thousand Ukrainians in the local administration carried out anti-Jewish measures under the watchful eye of their German supervisors. ${ }^{70}$ Yet there were also "cases in which Ukrainians in and outside the administration came willingly to the Germans and denounced Jews. ${ }^{171}$ Rein has noted that one of the most tragic aspects of the Holocaust was the fact that "often among the persecutors of the Jews were people who before the war had been friends, acquaintances, business partners, colleagues, clients, or patients." ${ }^{72}$ Similarly, in Crimea the female collaborators denounced fellow neighbours, friends and family. Some motivating factors for denouncing were blind obedience to the authorities, careerism and material gain. Yet sometimes the motivation was very personal. Emotions such as jealousy or revenge influenced women's actions. Koroleva, for example, denounced a friend's family for allegedly expressing pro-Soviet sentiments. In the post-war trial a witness testified that Koroleva had in fact had a falling out with her friend over money. ${ }^{73}$ Koroleva lacked stable financial support or close ties with the administration. Denunciation was an opportunity to at the same time benefit financially and settle a personal quarrel. Family feud caused Trubach to denounce her own sister. She admitted that her sister "often spoke against the Nazis and told me that when the Red Army returns I will be hung for treason. I will be honest, I denounced my sister because we had very bad relations for years, and she had always hated and criticized me." ${ }^{74}$ In his study of collaboration in

\footnotetext{
${ }^{67}$ Sheila Fitzpatrick, Everyday Stalinism. Ordinary life in extraordinary times: Soviet Russia in the 1930s (New York: Oxford University Press, 1999).

${ }^{68}$ Rein, 2011, p. 273.

${ }^{69}$ Women wrote in their memoirs about receiving sewing machines, dresses and other good for high productivity, Fitzpatrick, 2005, p. 148.

${ }^{70}$ Lower, 2004, p. 92.

71 Ibid.

${ }^{72}$ Rein, 2011, p. 270.

${ }^{73}$ USHMM, RG 31.018M, 6919, reel 77, p. 21285.

${ }^{74}$ USHMM, RG 31.018M, 13619, reel 56, p. 723.
} 
Belorussia Rein also found that "family bonds did not always protect Jews from condemnation to the German authority or local police." ${ }^{75} \mathrm{He}$ described a case where a woman was denounced by her own mother-in-law and another where a husband was denounced by his own wife. ${ }^{76}$ Lower argues that locals exploited Nazi anti-Semitism as well as partisan paranoia in order to "curry favour with the Nazis, improve their own conditions, and settle scores with foes." ${ }^{17}$

\section{Conclusion}

Women of ethnic German background were targeted by the occupying forces for collaboration due to their racial superiority, potential history of repression by Soviets and their knowledge of German and local languages. Nevertheless, being ethnically German did not automatically dispose women to collaboration. Polian has argued that Soviet authorities' charges of treason towards ethnic minorities "were both unfair and hypocritical" as out of 60 to 70 million people who found themselves in occupation, only around one million actively collaborated and an overwhelming majority of them were Ukrainian and Russian. ${ }^{78}$ My sample of collaborators reflects these statistics as more than half of the women were either Russian or Ukrainian. Neither ethnicity nor socio-economic background was a commonality between the women collaborators; some came from repressed families, some from peasant and others from proletarian backgrounds. In fact, despite their gender these women had no overwhelming similarities. Their stories are all very different.

Women collaborators came to work for the occupation in different capacities and under different circumstances. Some stayed behind by choice while others simply failed to evacuate. Some were interned in prisons. Some women had families to take care of while others were on their own. In order to save one's life from immediate threat such as prison or execution they had to collaborate, to follow orders. In order to make a living the women had to work. Sometimes they remained in the same position while others were offered new opportunities for employment. Some women got by being accommodating and just doing their job, while others expressed initiative and utilised opportunities that presented themselves in order to gain financial stability, elevate their social status or yield power over others. Some had no hand in violence while others became witness or even culprits. When asked by the post-war crime trial investigators why these women collaborated they gave very different answers. Tubach, for example, began denouncing people because she wanted to impress her superiors. She denounced her own sister to settle a personal score. During post-war trial interrogations she claimed she denounced because it was just part of her job. My study of women collaborators in occupied Soviet Ukraine has found no one homogenous collaborator; the circumstances and reasons for their actions were as individual as the women themselves.

\footnotetext{
${ }^{75}$ Rein, 2011, p. 264.

${ }^{76}$ Ibid.

${ }^{77}$ Lower, 2013, p. 94.

${ }^{78}$ Polian, 2004, p. 125.
} 